\title{
Could Serotonin Play a Role in Sudden Infant Death?
}

$\mathrm{S}^{\mathrm{u}}$ udden infant death syndrome (SIDS) is a condition characterized by the unexpected and unexplained death of an otherwise healthy infant aged between a month and a year. To be classified as SIDS, the death cannot be attributed to any other known cause after performance of a complete autopsy, examination of the death scene, and clinical history of the infant's family (1). Typically, the infant is found dead in the early morning after a sleep period and despite declines in the syndrome rates after risk reduction campaigns, SIDS remains the leading cause of postneonatal mortality in the United States with an incidence of $0.6 / 1000$ live births.

The triple-risk model for the pathogenesis of SIDS proposed by Kinney and coworkers (2) proposes that sudden death results when three risk factors occur simultaneously: 1) an underlying vulnerability; 2) a critical period for homeostatic control; and 3) an exogenous stressor. The underlying vulnerability remains latent until the infant enters a critical developmental period (the first 6 mo of life when $90 \%$ of SIDS deaths occur) and is exposed to an exogenous stressor. Epidemiologic risk factors of importance for SIDS include maternal smoking, socioeconomic disadvantage, prematurity, maternal obstetric history, infant sleeping practices, and sleep environment (3).

Much attention has been focused recently on the neurotransmitter serotonin and a specific region of the brain, the ventral medulla, which contains serotonergic neurons that innervate brain stem and spinal cord structures important for homeostatic control of respiratory drive, blood pressure, thermoregulation, and arousal. A failure of these serotonin neurons to maintain or promote homeostatic responses to life-threatening challenges (i.e., asphyxia, hypoxia, hypercapnia) during sleep could result in sudden death. Recently, several postmortem studies have reported morphologic and biochemical deficits in ventral medullary serotonin neurons in SIDS brains $(4,5)$. Immunohistochemical analysis revealed an increased number of serotonin neurons, as well as an increase in the fraction of serotonin neurons showing an immature, granular cell morphology suggesting a failure or delay in the maturation of these neurons in SIDS infants. However, it is not known whether deficits in ventral medulla serotonin neurons could be sufficient by themselves to cause catastrophic changes in autonomic function.

Using transgenic mice with selective alterations in serotonin neurons, we have recently shown that defective serotonin homeostasis alone is sufficient to precipitate catastrophic autonomic failure and

sudden death in mice (6). In mammals, normal levels of serotonin neuron activity are maintained by negative feedback inhibition via the serotonin receptor 1A (Htrla). In our transgenic mice, the autoinhibitory capacity of serotonin neurons has been increased by the tissue-type specific and reversible overexpression of Htr1a. Unexpectedly, while mice completely lacking serotonin (7) or serotonin neurons $(8,9)$ are viable, mice with increased auto-inhibition exhibited sporadic bradycardic and hypothermic crises that occurred during a limited developmental period and frequently progressed to death. Moreover, overexpressing mice failed to activate autonomic target organs (brown adipose tissue) in response to environmental challenge. These findings demonstrate that excessive serotonin auto-inhibition is sufficient to precipitate life-threatening autonomic dysregulation and confirms that altered serotonin homeostasis may be an underlying vulnerability contributing to SIDS. - Enrica Audero and Cornelius Gross

\section{REFERENCES}

1. Willinger M, James LS, Catz C 1991 Defining the sudden infant death syndrome (SIDS): deliberations of an expert panel convened by the National Institute of Child Health and Human Development. Pediatr Pathol 11:677-684

2. Filiano JJ, Kinney HC 1994 A perspective on neuropathologic findings in victims of the sudden infant death syndrome: the triple-risk model. Biol Neonate 65:194-197

3. Sahni R, Fifer WP, Myers MM 2007 Identifying infants at risk for sudden infant death syndrome. Curr Opin Pediatr 19:145-149

4. Kinney HC, Randall LL, Sleeper LA, Willinger M, Belliveau RA, Zec N, Rava LA, Dominici L, Iyasu S, Randall B, Habbe D, Wilson H, Mandell F, McClain M, Welty TK 2003 Serotonergic brainstem abnormalities in Northern Plains Indians with the sudden infant death syndrome. J Neuropathol Exp Neurol 62:1178-1191

5. Paterson DS, Trachtenberg FL, Thompson EG, Belliveau RA, Beggs AH, Darnall R, Chadwick AE, Krous HF, Kinney HC 2006 Multiple serotonergic brainstem abnormalities in sudden infant death syndrome. JAMA 296:2124-2132

6. Audero E, Coppi E, Mlinar B, Rossetti T, Caprioli A, Banchaabouchi MA, Corradetti R, Gross C 2008 Sporadic autonomic dysregulation and death associated with excessive serotonin autoinhibition. Science 321:130-133

7. Gutknecht L, Waider J, Kraft S, Kriegebaum C, Holtmann B, Reif A, Schmitt A, Lesch KP 2008 Deficiency of brain 5-HT synthesis but serotonergic neuron formation in Tph2 knockout mice. J Neural Transm 115:1127-1132

8. Hendricks TJ, Fyodorov DV, Wegman LJ, Lelutiu NB, Pehek EA, Yamamoto B, Silver J, Weeber EJ, Sweatt JD, Deneris ES 2003 Pet-1 ETS gene plays a critical role in 5-HT neuron development and is required for normal anxiety-like and aggressive behavior. Neuron 37:233-247

9. Zhao ZQ, Scott M, Chiechio S, Wang JS, Renner KJ, Gereau RW, Johnson RL, Deneris ES, Chen ZF $2006 \mathrm{Lmx} 1 \mathrm{~b}$ is required for maintenance of central serotonergic neurons and mice lacking central serotonergic system exhibit normal locomotor activity. J Neurosci 26:12781-12788 